\title{
STRATEGI PEMBERDAYAAN APARATUR SIPIL NEGARA DALAM MENINGKATKAN PELAYANAN PUBLIK DI KANTOR KECAMATAN TALLO KOTA MAKASSAR
}

\section{STRATEGIES FOR EMPOWERMENT OF STATE CIVIL APPARATUS IN IMPROVING PUBLIC SERVICES IN THE TALLO DISTRICT OFFICE, MAKASSAR CITY}

\author{
Lukman Arifin ${ }^{1}$ \\ Sekolah Tinggi Ilmu \\ Sosial dan Politik 17-8- \\ 1945 Makassar, \\ Indonesia $^{1}$ \\ email: \\ lukmanarifinbelawa@g \\ mail.com
}

IJI Publication p-ISSN: 2774-1907 e-ISSN: 2774-1915 Vol. 1, No. 2, pp. 105114 , Maret 2021

\footnotetext{
Unit Publikasi Ilmiah Intelektual Madani Indonesia
}

Abstrak: Penelitian ini bertujuan untuk mengetahui dan menjelaskan; 1) Pemberdayaan Aparatur Sipil Negara (ASN) di Kantor Kecamatan Tallo Kota Makassar dan 2) Strategi pemberdayaan sumber daya manusia aparatur dalam pelayanan publik dari aspek pelayanan administrasi kependudukan di Kantor Kecamatan Tallo Kota Makassar. Penelitian ini menggunakan pendekatan kualitatif dengan metode analisis deskriptif dalam rangka menemukan fakta dan interprestasi secara tepat dan akurat mengenai fenomena-fenomena kelompok maupun individu pada tataran empirik. Teknik pengujian keabsahan data yang digunakan dalam penelitian ini menggunakan model interaktif untuk menganalisis data hasil penelitian. Aktivitas dalam analisis data kualitatif dilakukan secara interaktif dan berlangsung secara terus menerus sampai tuntas dan diperoleh data jenuh. Hasil penelitian menunjukkan bahwa; 1) secara umum pemberdayaan Aparatur Sipil Negara (ASN) pada Kantor Kecamatan Tallo Kota Makassar telah dilaksanakan cukup baik, dilihat dari dimensi; a) keinginan, b) kepercayaan, c) kepercayaan diri, d) kredibilitas, e) akuntabilitas, dan f) komunikasi dan 2) strategi pemberdayaan Aparatur Sipil Negara (ASN) dalam meningkatkan kualitas pelayanan publik di Kantor Kecamatan Tallo Kota Makassar dilihat dari dimensi; a) berhubungan dengan visi, b) komunikasi aktif, dan c) menguatkan kerja tim pada dasarnya cukup efektif.

Kata Kunci: Strategi, Pemberdayaan SDM, Pelayanan Publik.

Abstract: This study aims to identify and explain; 1) Empowerment of State Civil Servants (ASN) in the Tallo District Office of Makassar City and 2) Strategies for empowering human resources for apparatus in public services from the aspect of population administration services at the Tallo District Office, Makassar City. This study uses a qualitative approach with descriptive analysis methods in order to find facts and interpretations accurately and accurately regarding group and individual phenomena at the empirical level. The data validity testing technique used in this study used an interactive model to analyze the research data. Activities in qualitative data analysis are carried out interactively and continuously until completion and saturated data are obtained. The results showed that; 1) In general, the empowerment of the State Civil Apparatus (ASN) at the Tallo District Office, Makassar City has been implemented quite well, seen from the dimensions; a) desire, b) trust, c) self-confidence, d) credibility, e) accountability, and f) communication and 2) strategies for empowering the State Civil Apparatus (ASN) in improving the quality of public services at the Tallo District Office, Makassar City seen from the dimensions; a) related to the vision, b) active communication, and c) strengthening teamwork is basically quite effective. and f) communication and 2) the strategy of empowering the State Civil Apparatus (ASN) in improving the quality of public services at the Tallo District Office, Makassar City, seen from the dimensions; a) related to the vision, b) active communication, and c) strengthening teamwork is basically quite effective. and f) communication and 2) strategies for empowering the State Civil Apparatus (ASN) in improving the quality of public services at the Tallo District Office, Makassar City, seen from the dimensions; a) related to the vision, b) active communication, and c) strengthening teamwork is basically quite effective.

Keywords: Strategy, Human Resource Empowerment, Public Service.

\section{PENDAHULUAN}

Pembangunan nasional merupakan rangkaian upaya yang dilakukan untuk meningkatkan kualitas sumber daya manusia dalam rangka mewujudkan tujuan nasional. Dalam Pembukaan Undang-Undang Dasar (UUD) 1945 alinea keempat, dijelaskan bahwa salah satu tujuan dari pembangunan nasional adalah untuk mewujudkan bangsa yang cerdas, agar dapat tercipta sumber daya manusia yang berkualitas, bertanggung jawab, maju serta mandiri yang menjadikan manusia yang seutuhnya baik dari segi sosial, ekonomi, serta budaya. 
Manajemen Sumber Daya Manusia (MSDM) merupakan suatu entitas penting dalam studi kelembagaan, baik dalam kelembagaan organisasi sosial, budaya, perusahaan, maupun lembaga pemerintah. Studi tentang MSDM di suatu kelembagaan pemerintah juga dapat ditunjukkan bagaimana misalnya lembaga merespon birokrasi yang berkembang di suatu kelembagaan pemerintahan modern saat ini, seperti persoalan rekruitmen, penempatan pegawai, dan pembinaan karier (Schuler, 1992). Manajemen sumber daya manusia yang sebagai salah satu unsur penting, memiliki arti dan fungsi strategis bagi suatu lembaga (Siagian, 2011). Berhasil atau tidaknya suatu lembaga dalam mencapai tujuan yang ditetapkan sangat tergantung kepada kemampuan SDM-nya dalam menjalankan tugas-tugas yang diberikan kepadanya. Oleh karena itu, setiap lembaga perlu memikirkan bagaimana cara yang dapat dilakukan untuk mengembangkan SDM agar dapat mendorong efektivitas pencapaian visi dan misi lembaga.

Dalam proses pembangunan manusia atau masyarakat, bukan hanya sebagai objek pembangunan, melainkan Juga berperan penting sebagai subjek pembangunan itu sendiri. Artinya, proses pembangunan harus melibatkan peran aktif masyarakat. Dengan perspektif ini, pembangunan pada saat yang bersamaan harus diarahkan guna memberdayakan masyarakat untuk berpartisipasi dalam proses pembangunan. Menempatkan manusia sebagai subjek pembangunan, berarti mengarahkan pembangunan untuk memenuhi tujuanya yang paling utama yaitu pemberdayaan. (Ali, 2009).

Sesuai hasil observasi awal yang dilakukan peneliti mengenai pemberdayaan pegawai pada Kecamatan Tallo menunjukkan belum maksimal dilihat dari proses pelayanan yang diberikan oleh pegawai kepada masyarakat mulai dari daya tanggap (responsif) yang kurang maksimal, hal ini terlihat ketika masyarakat datang di kantor kecamatan untuk melakukan pengurusan kependudukan, itu kurang di tanggapi oleh pegawai atas apa yang menjadi kebutuhan masyarakat. Selanjutnya sikap empati (empaty) yang terlihat pula masih kurang baik di karenakan di saat pegawai melayanai masyarakat tidak ada bentuk perilaku keseriusan dan keramahan. Permasalahan lainnya yang nampak pada Kantor Kecamatan Tallo Kota Makassar terkait dengan kepastian waktu (assurance) yang juga terbilang masih kurang maksimal dalam pemberian pelayanan, hal ini dibuktikan dengan adanya antrian panjang dan menunggu lama proses pelayanan dan masyakat tidak terlau diperhatikan sehingga masyarakat tidak merasa puas atas layanan diterima. Proses pelaksanan tugas dan tanggung jawab dalam menggunakan IT masih belum terlalu mahir untuk semua pegawai, hal ini dibuktikan dengan adanya masyarakat yang dilayani dengan menginput data akan tetapi waktu yang digunakan dalam menginput data cukup lama.

\section{METODE}

Jenis penelitian yang digunakan ialah penelitian deskripstif kualitatif. Penelitian deskripstif kualitatif yang bertujuan untuk mengungkapkan kejadian dan fakta, keadaan, fenomena, variabel dan keadaan yang terjadi saat penelitian berlangsung dengan menyuguhkan apa yang sebenarnya terjadi. Penelitian ini dilakukan di Kantor Kecamatan Tallo Kota Makassar.

Pendekatan Penelitian ini merupakan penelitian deskriptif kualitatif yaitu penelitian yang menggambarkan secara naratif dengan berdasar pada data-data hasil penelitian yang ditelaah secara objektif dari hasil wawancara, observasi, penelaahan dokumen. Dimana Sugiyono (2011) menyatakan bahwa metode deskriptif adalah suatu metode yang digunakan untuk menggambarkan atau 
menganalisis suatu hasil penelitian tetapi tidak digunakan untuk membuat kesimpulan yang lebih luas.

\section{HASIL DAN DISKUSI}

Kecamatan Tallo Kota Makassar merupakan salah satu dari 14 Kecamatan di Kota Makassar yang terletak sebelah utara Kota Makassar dengan pusat pemerintahannya berada di Kelurahan Ujung Pandang Baru, yang berbatasan dengan Selat Makassar di sebelah Utara, Kecamatan Tamalanrea di sebelah Timur, Kecamatan Bontoala sebelah Selatan dan Kecamatan Ujung Tanah di sebelah Barat. Dari catatan sejarah, Kecamatan Tallo merupakan peninggalan sejarah yang fundamental dengan keberadaan Kompleks Makam Kuno Raja-Raja Tallo. Dimana pada zamannya Raja Tallo Sultan Abdullah Awwalul Islam yang pertama kali memeluk agama Islam yang menandai hari lahirnya Kota Makassar.

Aparatur Sipil Negara di Kantor Kecamatan Tallo Kota Makassar berdasarkan data yang diperoleh Kantor Kecamatan Tallo yaitu berjumlah 49 orang. Terdiri dari Aparatur Sipil Negara (ASN), ) dan Tenaga Kontrak. Berikut tabel mengenai jumlah pegawai Kantor Kecamatan Tallo Kota Makassar:

Tabel 1

Jumlah Aparatur Kantor Kecamatan Tallo Kota Makassar

\begin{tabular}{|l|c|c|c|}
\hline \multicolumn{1}{|c|}{ Jenis Kelamin } & ASN & Kontrak & Jumlah \\
\hline Laki-laki & 8 & 23 & 31 \\
\hline Perempuan & 8 & 10 & 18 \\
\hline Total & 16 & 33 & 49 \\
\hline
\end{tabular}

Sumber: Kantor Kecamatan Tallo Kota Makassar 2018

Penyajian data hasil penelitian ini diperoleh dari hasil wawancara langsung antara penulis dengan beberapa informan dan data-data lain yang dapat mendukung penelitian ini.

Data yang penulis sajikan berkaitan dengan strategi pemberdayaan Aparatur Sipil Negara (ASN) dalam meningkatkan kualitas pelayanan publik di Kantor Kecamatan Tallo Kota Makassar. Penelitian dilatarbelakangi keinginan untuk memahami kontens strategi pemberdayaan dan kualitas pelayanan di lingkungan Kantor Kecamatan Tallo Kota Makassar, dalam rangka UU No. 5 Tahun 2014 tentang Aparatur Sipil Negara. Ini bertujuan untuk menentukan strategi terbaik dalam pengimplementasian peraturan perundang-undangan untuk jangka panjang agar bisa dicapai peningkatan kinerja, efektifitas, efesiensi, serta produktifitas Aparatur Sipil Negara dalam bekerja berdasarkan UU ASN.

\section{Pemberdayaan Aparatur Sipil Negara (ASN) di Kantor Kecamatan Tallo Kota Makassar}

Pemberdayaan menyangkut tentang kewenangan dan penguatan otoritas dari ASN tertentu. Pasalnya karena adanya kepercayaan dari pihak manajemen kepada ASN. Pada hakekatnya pemberdayaan adalah pengembangan mentalitas "mampu berkarya" yang positif dalam diri ASN (creating a positive "can do" mentality among employees). Mentalitas "mampu berkarya" ini tumbuh dari keyakinan diri para ASN akan kemampuannya untuk berkarya pada pekerjaannya (self-efficacy). Keyakinan ini ditumbuhkan melalui proses pengembangan kompetensi-kompetensi ASN, pemberian dorongan dan persuasi terus menerus, serta dukungan emosional dan keteladanan (modelling) dari para pimpinan di dalam kancah kegiatan kerja para ASN sehari-hari. Selanjutnya dikemukakan bahwa pemberdayaan adalah aktivitas yang terfokus pada pemberian kekeluasaan (liberating), bukan pengendalian (controlling), kepada ASN untuk mengaktualisasikan energinya, dan untuk menselaraskan (balancing) pencapaian tujuan pribadi ASN (pengembangan diri, kesejahteraan, dan lain-lain) dan tujuan yang ditetapkan organisasi (produktivitas, efisiensi, profitabilitas, dan lain-lain).

Hasil-hasil yang dicapai dalam menerapkan konsep pemberdayaan di berbagai kantor adalah peningkatan efisiensi 
dan kualitas dalam produksi dan pelayanan. Walau pemberdayaan merupakan proses pembelajaran bagi ASN, namun dalam prakteknya tidak semua organisasi sudah melakukannya. Kalau memang ada tetapi tidak semua pengambilan keputusan sisi kebijakan diberikan kepada ASN. Beberapa hal yang sangat strategis seperti penyusunan anggaran program, perencanaan kebutuhan sumberdaya manusia, perekrutan dan penseleksian ASN, masih merupakan keputusan pihak manajemen atau pimpinan.

Ada beberapa model atau strategi dalam kaitannya dengan upaya pemberdayaan ASN, antara lain: yaitu dengan strategi coaching dan counceling, model kepemimpinan situasional yaitu upaya untuk memberdayakan karyawan melalui peningkatan "kemampuan dan kemauan" ASN.

Proses coaching dan counseling seringkali dilakukan dalam waktu yang bersamaan. Meskipun demikian, terdapat perbedaan yang mendasar di antara kedua proses ini. Sebagai proses yang bertujuan membantu karyawan agar bisa menunjukkan kinerja yang optimal, coaching dan counseling dibedakan berdasarkan jenis sumber masalah yang menghambat kinerja seseorang.

Coaching merupakan sebuah proses bantuan yang dilakukan ketika karyawan mengalami masalah kinerja yang disebabkan oleh keterbatasan pemahaman terhadap tugasnya. Sedangkan Counseling, merupakan proses bantuan yang dilakukan ketika karyawan mengalami masalah kinerja disebabkan oleh adanya masalah dalam kehidupan pribadinya. Kebanyakan pemimpin menganggap coaching dan counseling sebagai satu hal, atau bahkan tertukar antara konsep coaching dan counseling.

Strategi pemberdayaan karyawan lainnya adalah dengan penerapan gaya kepemimpinan yang sesuai dengan level kematangan pengikut yaitu model kepempinan situasional. Model ini mengungkap kan bagaimana pemimpin berupaya untuk meningkatkan level "kematangan' yaitu "kemampuan" dan "kemauan" karyawan dalam pelaksanaan tugas pekerjaan yang dibebankannya. Model ini mengemukakan bahwa untuk meningkatkan level kematangan seseorang adalah dengan menggunakan gaya kepemimpinan yang sesuai dengan level kematangan orang tersebut. Ada empat gaya kepemimpinan yang mampu mengatasi persoalan karyawan yaitu meningkatkan level kematangan bawahan (terberdayanya karyawan), jika diterapkan secara konsisten sesuai dengan level kematangan pengikut.

Model pemberdayaan yang merupakan serangkaian proses yang dilakukan secara bertahap adalah sebagai berikut :

\section{Keinginan}

Segala kebutuhan lebih terhadap barang ataupun jasa yang ingin dipenuhi setiap manusia pada sesuatu hal yang dianggap kurang. Keinginan selalu ingin dipenuhi dengan cepat. keinginan masyarakat merupakan peluang besar bagi lembaga untuk mendapatkan keuntungan melalui jasa/layanan yang ditawarkan. Memberikan pelayanan prima kepada masyarakat atau penerima layanan diharapkan dapat meningkatkan loyalitas kepada perusahaan.

Sesuai dengan hasil penelitian bahwa pegawai sudah berupaya maksimal untuk memberikan pelayanan kepada masyarakat, sekiranya masyarakat merasa terpuaskan terhadap layanan yang diberikan. Akan tetapi biasanya terjadi permasalahan atau layanan yang dianggap lama, karena masyarakat sendiri kadang tidak melengkapai berbagai persyaratan-persyaratan sesuai ketentuan atau standar operasional prosedur (SOP) terutama pada pengurusan pengadaan E-KTP.

\section{Kepercayaan}

Kepercayaan sebagai kemauan individu untuk menjadikan organisasi sebagai tempat 
yang dipercayai untuk bergantung. kepercayaan sebagai harapan, asumsi, belief yang ada pada diri seseorang bahwa tindakan atau perilaku orang lain akan menguntungkan atau setidaknya tidak akan merusak minat dirinya. Kepercayaan yang dibahas dalam analisa ini adalah kepercayaan terhadap pegawai. kepercayaan ini merupakan hal yang penting dalam organisasi.

Sesuai dengan hasil penelitian bahwa pegawai pada Kantor Kecamatan Tallo masalah kepercayaan kepada pegawai cukup karena sesungguhnya dalam pelaksanakan pekerjaan itu sudah dibagi sesuai dengan tupoksi masing-masing, jadi pegawai bekerja dengan pekerjaanya atau tanggung jawab, tentu harus saling mempercayakan antara masing-masing pegawai untuk menuntaskan pekerjaan. Pimpinan sesekali mendelegasikan wewenangnya kepada bawahan apabila pimpinan sibuk itu menunjukan bahwa kepercayaan cukup tinggi.

Membangun kepercayaan antara pimpinan dan pegawai sesungguhnya sesuatu yang sangat penting hal tersebut didukung oleh teori secara idealitas. Hal-hal yang termasuk dalam keprcayaan antara lain: (1) memberi kesempatan pada karyawan untuk berpartisipasi dalam pembuatan kebijakan, (2) menyediakan waktu dan sumber daya yang mencukupi bagi karyawan dalam menyelesaikan kerja, (3) menyediakan pelatihan yang mencukupi bagi kebutuhan kerja. (4) menghargai perbedaan pandangan dan menghargai kesuksesan yang diraih oleh karyawan. (5) menyediakan akses informasi yang cukup.

Kepercayaan atara pegawai yang sudah terbagun pada Kantor Kecamatan Tallo seyogianya tetap dipertahankan atau lebih ditingkatkan agar pelayanan bisa maksimal terutama pada waktu pelayan karena biasanya membutuhkan waktu yang lama jika ada pekerjaan yang tidak saling mempercayai antara pegawai dengna pimpinan atau atara sesama pegawai.

\section{Kepercayaan Diri}

Sikap positif seorang individu yang memampukan dirinya untuk mengembangkan penilaian positif baik terhadap diri sendiri maupun terhadap lingkungan atau situasi yang dihadapinya. Hal ni bukan berarti individu tersebut mampu dan kompenten melakukan segala seuatu seorang diri. Rasa percaya diri yang tinggi sebenarnya hanya merujuk pada memiliki kompetensi, yakin. Mampu dan percaya bahwa dia bisa karena didukung oleh pengalaman, potensi aktual, prestasi serta harapan yang realistik terhadap diri sendiri.

Sesuai dengan hasil penelitian bahwa pimpinan sangat memberikan kesempatan yang sebesar-besarnya kepada pegawai untuk mengembangan potensinya terutama dalam pengembangan lembaga dan sangat terbuka untuk membangun jaringan dengan lembaga yang lain.

Kepercayaan diri pegawai sangat penting karena dengan kepercaya diri maka akan lebih mudah berkreasi dan pengembangan diri untuk melakuan pekerjaan dan tanggungjawabnya, hal tersebut juga sangat didukung oleh konsep teori kepercayaan diri yang termasuk tindakan yang dapat menimbulkan selef confident antara lain: (1) mendelegasikan tugas yang penting terhadap karyawan, menggali ide dan saran dari karyawan, (3) memperluas tugas dan membangun jaringan antar departemen. (4) menyediakan jadwal job instruction dan mendorong penyelesaian yang baik.

Kepercayaan diri pegawai pada Kantor Kecamatan Tallo cukup tinggi, karena pimpinan sangat mengapresiasi atau membuka ruang kepada pegawai untuk pengembangan SDM dengan memberikan kesempatan untuk ikut pendidikan dan pelatihan sehingga pegawai merasa percaya 
diri dengan kemampuan yang dimiliki untuk melayani kepada masyarakat, tentu kepercayaan tersebut harus selalu ditingkatkan dengan memaksimal pegembangan komptensi pegawai.

\section{Kredibility}

Kredibilitas pada umumnya merupakan kemampuan seorang pegawai dalam memberikan layanan dengan efektif. Kredibilitas merupakan hal yang penting bagi penilaian seorang. Kredibilitas, selain mempunyai keterkaitan dengan faktor kejujuran juga terkait dengan hal-hal yang bersifat psikologis yang mengacu pada kepercayaan dan juga ketertarikan seseorang.

Kredibilitas juga diartikan sebagai kualitas, kapabilitas, atau kekuatan untuk menimbulkan kepercayaan. Pegawai yang kredibel akan dipercaya dan membuat masyarakat yang dilayani terbuka dalam menyampaikan informasi personal serta bertanya tentang berbagai hal mengenai program layanan. Kredibilitas akan tercermin dari pengetahuan atau pemahaman terhadap layanan. Kepercayaan yang dibangun akan memberikan dampak yang baik untuk kelangsungan perkembangan maupun pertumbuhan bagi lembaga atau organisasi.

Sesuai dengan hasil penelitian menyatakan bahwa para pegawai pada Kantor Kecamatan Tallo merupakan sesuatu yang seyogianya diberdayakan karena sesusungguhnya maju mundurya suatu lembaga tergantung sumber daya manusia. Pegawai merupakan partner pengerak utama terhadap kesuksesan atau terselenggaranya program. Kepercayaan yang diberkan kepada karyawan akan lebih mudah megerjakan pekerjaan sehingga target-target yag telah ditentukan bisa tercapai.

Kredibilitas dengan penghargaan dan mengembangkan lingkungan kerja yang mendorong kompetisi yang sehat sehingga tercipta organisasi yang memiliki performance yang tinggi sesuai dengan konsep teori yang adaya yaitu: (a) memandang karyawan sebagai partner strategis, (b) peningkatan target di semua bagian pekerjaan, (c) memperkenalkan inisiatif individu untuk melakukan perubahan melalui partisipasi, (d) membantu menyelesaikan perbedaan dalam penentuan tujuan dan priorotas

Tercapainya target-target dalam pekerjaan tidak terlepas dari keredibilitas para pegawai. Pimpinan seyogianya harus lebih memberikan kesempatan kepada para pegawai untuk mengaktualisasikan dirinya dalam bekerja sehingga semakin kredibel dalam melaksanakan tugas dan tanggung jawabnya.

\section{Akuntabilitas}

$\begin{array}{llr}\text { Akuntabilitas } & \text { dapat } & \text { merupakan } \\ \text { pengetahuan } & \text { dan } & \text { adanya }\end{array}$ pertanggungjawaban tehadap tiap tindakan, pelayanan, keputusan dan kebijakan termasuk pula didalamnya administrasi publik pemerintahan, dan pelaksanaan dalam lingkup peran atau posisi kerja yang mencakup di dalam mempunyai suatu kewajiban untuk melaporkan, menjelaskan dan dapat dipertanyakan bagi tiap-tiap konsekuensi yang sudah dihasilkan.

Akuntabilitas merupakan istilah yang terkait dengan tata kelola pemerintahan sebenarnya agak terlalu luas untuk dapat didefinisikan. akan tetapi hal ini sering dapat digambarkan sebagai hubungan antara yang menyangkut saat sekarang ataupun masa depan, antar individu, kelompok sebagai sebuah pertanggungjawaban kepentingan merupakan sebuah kewajiban untuk memberitahukan, menjelaskan terhadap tiaptiap tindakan dan keputusannya agar dapat disetujui maupun ditolak atau dapat diberikan hukuman bilamana diketemukan adanya penyalahgunaan kewenangan.

Sesuai dengan hasil penelitian bahwa pada Kantor Kecamatan Tallo pegawai diberikan kesempatan untuk ikut pelatihan dalam rangka pengembangan SDM, agar 
mereka mampu melaksanakan atau bertanggungjawab terhadap tugas yang diberikan. Pertanggung jawaban pegawai pada wewenang yang diberikan. Dengan menetapkan secara konsisten dan jelas tentang peran, standar dan tujuan tentang penilaian terhadap kinerja pegawai, tahap ini sebagai sarana evaluasi terhadap kinerja pegawai dalam penyelesaian dan tanggung jawab terhadap wewenang yang diberikan. Hal yang termasuk accountability antara lain: (1) menggunakan jalur training dalam mengevaluasi kinerja karyawan, memberikan tugas yang jelas dan ukuran yang jelas, (3) melibatkan karyawan dalam penentuan standar dan ukuran, memberikan saran dan bantuan kepada karyawan dalam menyelesaikan beban kerjanya, (5) menyediakan periode dan waktu pemberian feedback.

Pertanggungjawaban pada istansi atau kantor memanglah sangat penting untuk membangun kepercayaan masyarakat yang menerima layana oleh karena itu pegawai pada Kantor Kecamatan Tallo seyogianya harus mempertaha akuntabilitasnya dengan keterlibatan pegawai dalam satandar ukuran dan pembagian job yang sesuai dengan kapabilitasnya.

\section{Komunikasi}

Komunikasi merupakan sarana yang digunakan para pegawai, baik secara formal maupun informal, untuk berdiskusi, bertukar pikiran, membuat laporan kepada atasan, memberikan arahan kepada bawahan dan sebagainya. Organisasi disusun untuk mengerjakan tugas dalam rangka mencapai tujuan yang mana di dalamnya para pimpinan, para bawahan, rekan-rekan yang setaraf, serta lingkungan eksternal perlu dihubungkan oleh proses-proses komunikasi. Komunikasi merupakan suatu faktor yang utama dalam organisasi. Hampir tidak ada aspek organisasi yang tidak melibatkan komunikasi.
Sesuai dengan hasil penelitian bahwa komunikasi merupakan sesuatu yang sangat penting dalam menyelenggarakan roda organisasi atau kelembagaan, oleh karena itu pegawai seyogianya harus membagun komunikasi aktif antara pimpinan dengan karyawa atau antara karyawan. Tidak ada pekerjaan bisa selesai dengan baik tanpa dikomunikasikan karena perkerjaan harus didiskusikan untuk membetuk kesepakatan bersama.

Sesuai dengan konsep teori bahwa keterbukaan komunikasi ini dapat diwujudkan dengan adanya kritik dan saran terhadap hasil dan prestasi yang dilakukan pekerja. Hal yang termasuk dalam communication antara lain: (1) menetapkan kebijakan open door communication, menyediakan waktu untuk mendapatkan informasi dan mendistribusikan permasalahan secara terbuka, menciptakan kesempatan untuk cross-training.

Kesuksesan dalam pelaksanaan pekerjaan pada Kantor Kecamatan Tallo sangat dipengaruhi oleh komunikasi yang berjalan lancar atau aktif oleh karena itu seyogianya mulai dari pimpinan, dan karyawan harus selalu membangun komunikasi aktif terutama dalam penyelenggaraan pekerjaan, terutama apabila ada kendala dalam pelaksanaan tugas agar segera dikomunikasikan untuk mencari solusi.

\section{Strategi Pemberdayaan Aparatur Sipil Negara (ASN) dalam meningkatkan kualitas Pelayanan Publik}

Pemberdayaan pegawai perlu diwujudkan melalui sejumlah strategi yang saling menunjang satu dengan yang lainnya, yaitu: berhubungan dengan visi, komunikasi aktif, menghargai capaian/ keberhasilan.

\section{Berhubungan Dengan Visi}

Pemberdayaan pegawai amat penting bagi peningkatam kinerja organisasi atau 
kinerja unit dan tim kerja. Asumsinya adalah jika seseorang pegawai bertumbuh-kembang dalam pemberdayaan yang maksimal, maka kinerjanya diharapkan juga akan meningkat. Kinerja pegawai secara individual memberikan kontribusi peningkatan kinerja organisasi. Konsep manajemen kinerja yang berhubungan dengan visi sangat menghargai peran pemberdayaan pegawai, karena didalam konsep tersebut terdapat beberapa komponen penting yang terkait dengan peran SDM. Didalam manajemen kinerja tercakup fungsi manajemen SDM secara khusus, yang disebut dengan penilaian kinerja bagi pegawai. Melalui penilaian kinerja pula, maka manajemen karir dan pengembangan karir pegawai dapat difasilitasi secara khusus.

Sesuai dengan hasil penelitian bahwa pemberdayaan pegawai sangat ditentukan oleh visi yang dirumuskan karena visi merupakan gambaran kedepan yang akan dicapai, tentu visi yang ada di Kecamatan Tallo sangat mendukung untuk peningkatan sumber daya manusianya terutama pada tupoksi kinerjanya demi menigkatkan kualitas pelayanan.

Para pegawai di Kecamatan Tallo pada umumnya telah paham terhadap visi yang akan dicapai, hal tersebut sesungguhnya memang harus dipahami oleh semua pegawai tanpa terkecuali karena jika tidak maka akan sulit dalam menjalankan tugas dan tanggung jawabnya atau atktualisasi visi dengan misi, maka dari itu seyoginaya pimpinan untuk lebih memberdayakan pegawai tentu salah satu tuntunya besarnya adalah melakukan kegaitan pemhaman atau semacam pertemuan/pelatihan untuk lebih paham terhadap visi, misi hingga bisa tercapai tujuan lembaga.

\section{Komunikasi Aktif}

Pemberdayaan pegawai merupakan kerangka penting bagi program pengembangan dan pelatihan SDM. Pengembangan pegawai memacu profesionalisme kerja pegawai dan sangat berhubungan dengan karir pegawai dalam jangka panjang, sedangkan pelatihan terkait dengan kompetensi dalam mengemban tugas tertentu dalam jangka waktu tertentu yang lebih pendek. Komunikasi aktif antar ASN dalam sebuah organisasi juga sangat mempengaruhi keberhasilan suatu Instansi agar ada umpan balik dari pegawai secara berkesinambungan, sehingga pemberdayaan dalam organisasi akan mampu bergulir dengan baik.

Sesuai dengan hasil penelitian bahwa komunikasi aktif sangat penting, segala seuatunya dalam kelembagaan terutama pada penyelenggaran program kerja pada Kantor Kecamatan Tallo harus dikomunikasikan, baik antara pimpinan dengan bawahan maupun antara pegawai. Sesungguhnya tidak ada masalah bisa terselesaikan tanpa adanya komunikasi.

Para pegawai di Kantor Kecamatan Tallo mulai dari pucuk pimpinan hingga bawahan tentu sudah membangun komunikasi yang baik, akan tetapi seyogianya semakin intensifkan komunikasi itu terutama terkait dengan mengkonikasi persoalanpersoalan yang terjadi agar segera bisa teratasi dengan waktu yang singkat, ataukah harus dilakuka pertemuan dalam sepekan untuk mengevaluasi kinerja-kinerja para pegawai.

\section{Menguatkan Kerja Tim}

Kerja sama tim sangatlah diperlukan dalam dunia kerja karena tidak ada orang yang dapat bekerja sendiri, terutama dalam sebuah lembaga. Tentu setiap kantor memerlukan berbagai cara membangun kerja sama tim yang efektif agar tujuan dari tim berhasil dan lembaga/kantor mencapai target pekerjaan. Kerja sama tim memang tidaklah mudah untuk dibangun. Perlu proses yang cukup panjang untuk memiliki tim yang solid dengan anggota-anggota yang saling memiliki kerja sama tim yang sehati. 
Sesuai dengan penelitian bahwa salah satu strategi untuk mengembangkan kemampuan SDM dalam pelayanan publik pada Kantor Kecamatan Tallo adalah harus ada penguatan kerja sama tim. Pekerjaan tidak bisa berjalan dengan maksimal apabila hanya mengharapkan kerja dari individu pegawai atau jalan sendiri-sendiri karena adakalanya harus saling membantu dengan yang lainnya apalagi pada kantor merupakan pekerjaan sistem artinya saling ketergantungan atara satu yang lainnya.

Para pegawai Kantor Kecamatan Tallo pada umumnya sudah bekerja secara tim, tetapi masih perlu dikembangkan atau ditingkatkan agar sekiranya pegawai betulbetul bisa bekerja secara kolektif/bersamasama demi mencapai target pekerjaan atau tereselengaranya segala program-program yang telah dirumuskan dan tentu dengan kerja tim pekerjaan tidak terlalu membebani atara satu dengan yang lainnya. Meningkatkan kerja sama tim bisa terjadi jika setiap anggota tim diperlengkapi dalam kompetensinya masing-masing. Dengan meningkatnya kompetensi mereka, semakin tinggi juga kinerja yang mereka lakukan.

\section{KESIMPULAN}

Sesuai dengan konsep teoritis dan temuan penelitian bahwa pemberdayaan ASN dengan 6 indikator yaitu mulai dari keinginan, kepercayaan, kepercayaan diri, kredibility, akuntabilitas, dan komunikasi merupakan satu kesatuan yang tidak terpisahkan karena saling melengkapi satu sama lain oleh karena itu seyogianya pegawai pada kantor Kecamatan Tallo harus lebih konsen untuk meningkatkan pemberdayaan terutama memperhatikan dan menjalankan 6 idikator tersebut sehingga jauh lebih baik demi tercapainya layanan prima atau pelayanan yang unggul. Sedangkan Pengembangan strategi Pemberdayaan Aparatur Sipil Negara (ASN) dalam meningkatkan kualitas pelayanan publik di
Kantor Kecamatan Tallo Kota Makassar dari dimensi berhubungan dengan visi, komunikasi aktif, dan menguatkan kerja tim dianggap belum cukup atau optimal oleh karena itu seyogianya semakin ditingkatkan pembinaan dan pelatihan kepada SDM dan perlu konsentrasi terhadap pengembangan strategi Inovasi, penguatan mutu serta strategi minimalkan penggurangan biaya layanan.

\section{REFERENSI}

Ali, F. (2009) Mendongkrak Produktivitas Udang Galah. Jakarta: Penebar Swadaya.

Aileen Mitchel Stewart. (1998). Empowering People. Yogyakarta: Kanisius.

Dessler, Gary. (2003) Manajemen Sumber Daya Manusia. Jilid I. Edisi 10. Jakarta: PT Indeks.

Effendy, O. U. (2007). Ilmu Komunikasi Teori dan Praktek, Cetakan kesembilanbelas. Bandung: PT Remaja Rosdakarya.

Handoko, Hani. (1999). Dasar-Dasar Manajemen Produksi dan Operasi. Yogyakarta.

Hasibuan, Malayu S.P. (2009). Manajemen Dasar, Pengertian, Dan Masalah. Jakarta: PT Bumi Aksara.

(2005). Manajemen

Sumber Daya Manusia. Edisi. Revisi. Jakarta: Bumi Aksara.

Haryati, S. (2006). "Studi Tentang Model Prediksi Tingkat Kesehatan Bank Umum Swasta Nasional Indonesia." Ventura, 9, (3), pp.1-19.

Khan. (2007). Pemberdayaan Sumber Daya Manusia. Yogyakarta: Andi Offset.

Mangkunegara, A.A.Anwar Prabu. (2011). Manajemen Sumber Daya Manusia Perusahaan. Bandung: PT Remaja Rosda Karya.

Marquardt, M.J. (2002). Building the learning organization. New York : McGrawHill.

M. Senge, Peter. (2006). The Fifth Discipline, The Art and Practice of The Learning 
Organization. Random house: Sutalaksana, A \& Tjakraatmadja. (2006).

Doubleday.

Miles, M.B, Huberman, A.M, dan Saldana, J. (2014). Qualitative Data Analysis, A Methods Sourcebook, Edition 3. USA: Sage Publications. Terjemahan Tjetjep Rohindi Rohidi, UI-Press.

Mintzberg, H. (2007). Mintzberg on Management. Free Press: New York.

Moekijat. (2001). Manajemen Personalia dan Sumber Daya Manusia. Bandung: Mandar Madju.

Pedler, P.M., Boydell, T.H., dan Burgoyne, J. (1988). Learning Company: Project Report Training Agency. New York: Mc.GrawHill Maiden Head.

Rangkuti, Freddy. (2009). Strategi Promosi yang Kreatif dan Analisis Kasus Integrated Marketing Communication. Jakarta: PT. GramediaPustakaUtama.

Porter, Michael, E. (2008). Strategi Bersaing (Competitive Strategy). Tanggerang: Karisma Publising Group. (1996). Strategi Bersaing : Teknik Menganalisis Industri dan Pesaing. Jakarta: Erlangga.

Sadili, Samsudin. (2006). Manajemen Sumber Daya Manusia. Yogyakarta: Pustaka Setia.

Schuler, R and Harris, D. (1992). Managing Quality. Massachusetts: AddisonWesley publishing Company Inc.

Sedarmayanti. (2009). Sumber Daya Manusia dan Produktivitas Kerja. Bandung: Penerbit Mandar Maju. (2014). Manajemen Sumber Daya Manusia, Reformasi Birokrasi, dan Manajemen Negeri Sipil. Bandung: Refika Aditama.

Sondang P. Siagian. (2011). Manajemen Sumber Daya Manusia. Jakarta: PT. Bumi Aksara.

Sunarno. (2007). Pemberdayaan Sumber Daya Manusia, Lembaga Administrasi Negara. Modul Diklatpim II, Jakarta.
"Teknik Perancangan Sistem Kerja". Departemen Teknik Industri Institut Teknologi Bandung.

Senge, Peter. (1990). The Fith Dicipline. Double day: USA.

Thoha, Miftah. (2012). Perilaku Organisasi Konsep Dasar dan Implikasinya. Jakarta :PT. Raja Grafindo Persada.

Undang-Undang Nomor 15 Tahun 2014 tentang Aparatur Sipil Negara. 